\title{
NOTE
}

\section{Photoperiodic control of diatom spore growth: a theory to explain the onset of phytoplankton blooms}

\author{
H. Chr. Eilertsen, S. Sandberg, H. Tøllefsen
}

Norwegian College of Fisheries Science, University of Tromsø, N-9037 Tromsø, Norway

\begin{abstract}
Photoperiod influences the timing of several growth processes in higher plants and macroalgae. Results from our experiments indicate photoperiodic control of germination and/or growth of diatom resting spores. We suggest that the onset of phytoplankton blooms in northerly areas, and possibly also further south, may be photoperiod dependent and linked to entrainment of phytoplankton resting spores from bottom sediments.
\end{abstract}

KEY WORDS: Phytoplankton · Spores · Daylength

Throughout several years of investigation we have observed that the timing of the phytoplankton spring bloom varies little in northern Norwegian coastal waters despite varying environmental conditions between years; the peak of the bloom can always be observed in mid-April (Gaarder 1938, Heimdal 1974, Schei 1974, Throndsen \& Heimdal 1976, Eilertsen et al. 1981, 1989).

The seasonal development of a pycnocline is widely accepted as being a prerequisite for the development of a phytoplankton bloom (Sverdrup 1953). However, in many inshore northerly areas (fjords) spring blooms occur in thoroughly mixed, vertically homogeneous water columns (Eilertsen et al. 1981, 1989) and cannot be explained by 'Sverdrup's paradigm' (Sverdrup 1953). One plausible explanation for this may be that although the fjords are deep (200 $\mathrm{m}$ or more), blooms may start near the shore where waters are shallower and where the phytoplankters are not transported to below their critical depth. This does not, however, explain how blooms can begin at approximately the same time in coastal waters under highly varying environmental conditions, nor why in some years the spring bloom might start at the same time in the open Barents Sea waters as near the coast. It may also be worthy of note that the spring bloom in a shallow $(4 \mathrm{~m})$ saltwater pond near Tromsø, Norway, followed essentially the same pattern (timing, species composition) as that in coastal waters despite the difference in environmental conditions (Pedersen et al. 1989).

Examination of the literature describing species composition and succession shows that high-diversity diatom blooms may occur at approximately the same time at southerly latitudes as at Spitzbergen and in northern Norway (Eilertsen et al. 1989). For example, the spring bloom maximum in the English Channel can be observed around mid-April (Gros \& Ryckaert 1983), when the water temperatures and daily insolation values are much higher than those observed further to the north. Thus there seem to be discrepancies between the mechanisms usually invoked to explain the onset of blooms (stability, light field) and the observed events.

It has already been suggested by Gran (1912) that resuspended resting spores formed seed populations for blooms. We therefore hypothesised that a large proportion of the phytoplankton contributing to the spring bloom was recruited from dormant cells (resting spores and cells) entrained from the bottom sediments via turbulent mixing during spring. Several preliminary experiments in which bottom sediments were collected during winter and grown in a continuous light regime showed that the source of the cells triggering the spring bloom may be spores contained in the bottom sediments. These sediment cultures comprised all the typical spring bloom species from the region, but the relative numbers of the species present were highly different from those that can be observed in field samples. We therefore modified the hypothesis to include the idea that the onset of blooms is regulated by photoperiod, similar to the regulation of several growth processes in higher plants and macroalgae (Vince-Prue 1975, Evans et. al. 1982, Dring \& Lüning 1983, Hay 1990). This note presents results from some of the experiments that we conducted in order to test this hypothesis. 
Materials and methods. Seawater was collected with 51 Niskin bottles at Svartnes in Balsfjord (185 m depth) and at Spildernes (240 $\mathrm{m}$ depth) in the Malangen fjord system, Norway (see Fig. 1). The deepest samples were collected approximately $5 \mathrm{~m}$ above the bottom. Phytoplankton identification and enumeration was performed by the inverted microscope technique on $100 \mathrm{ml}$ water samples preserved with $2 \mathrm{ml}$ of $40 \%$ formaldehyde neutralised with hexamine. Chlorophyll a was measured by the fluorometric technique after extraction in methanol (Holm-Hansen et al. 1965). Each measuring point in Fig. 1 is the mean of 2 samples.

The sediment that was used for the daylength experiments was collected at Svartnes in Balsfjord on 25 October 1993 and kept at bottom sea temperature $\left(\sim 4.0^{\circ} \mathrm{C}\right)$ in total darkness for $6 \mathrm{wk}$ before the first experiment started on 9 December 1993. The cultures were prepared by diluting the sediment with autoclaved seawater (1:10). Thereafter this suspension was diluted 100 times with f/2 medium (Guillard \& Ryther 1962) and exposed to different daylengths and scalar irradiances (daylengths: 7, 11, 13 and $17 \mathrm{~h}$; scalar irradiances: 2, 25 and $55 \mu \mathrm{mol}$ quanta $\mathrm{m}^{-2} \mathrm{~s}^{-1}$ ) in $250 \mathrm{ml}$ Erlenmeyer glass bottles for each experimental condition. The second type of experiment was performed by first exposing the sediment cultures to low light ( $2 \mu \mathrm{mol}$ quanta $\mathrm{m}^{-2} \mathrm{~s}^{-1}$ ) at the same daylengths as in the first experiment for 2,7 or $14 \mathrm{~d}$ before they were transferred to $7 \mathrm{~h}$ daylength at $55 \mu \mathrm{mol}$ quanta $\mathrm{m}^{-2} \mathrm{~s}^{-1}$. The experiments were performed with 3 experimental bottles for each condition. The temperature was kept at $5^{\circ} \mathrm{C}$ and the vessels were stirred manually twice daily. The cell numbers presented in the tables (see Tables $2 \& 3$ ) are mean values from the 3 bottles under each experimental condition. Counting of cells was performed within $4 \mathrm{~h}$ after sampling by the inverted microscope technique $(2 \mathrm{ml}$ settling chambers). The samples (sedimenting chambers) were kept at experimental conditions until they were counted. During the incubation period all bottles were checked (counted) weekly. Cell numbers below 5 cells $\mathrm{ml}^{-1}$ are omitted in the tables, and the reported numbers are rounded and represent mean values from the 3 bottles. Where possible a minimum of 300 cells of each species was counted. Numbers below 5 cells $\mathrm{ml}^{-1}$ are omitted in the tables.

Results. The vertical profiles of chlorophyll a and cell numbers (Fig. 1, Table 1) show enhanced chlorophyll concentrations and cell numbers near the bottom and in

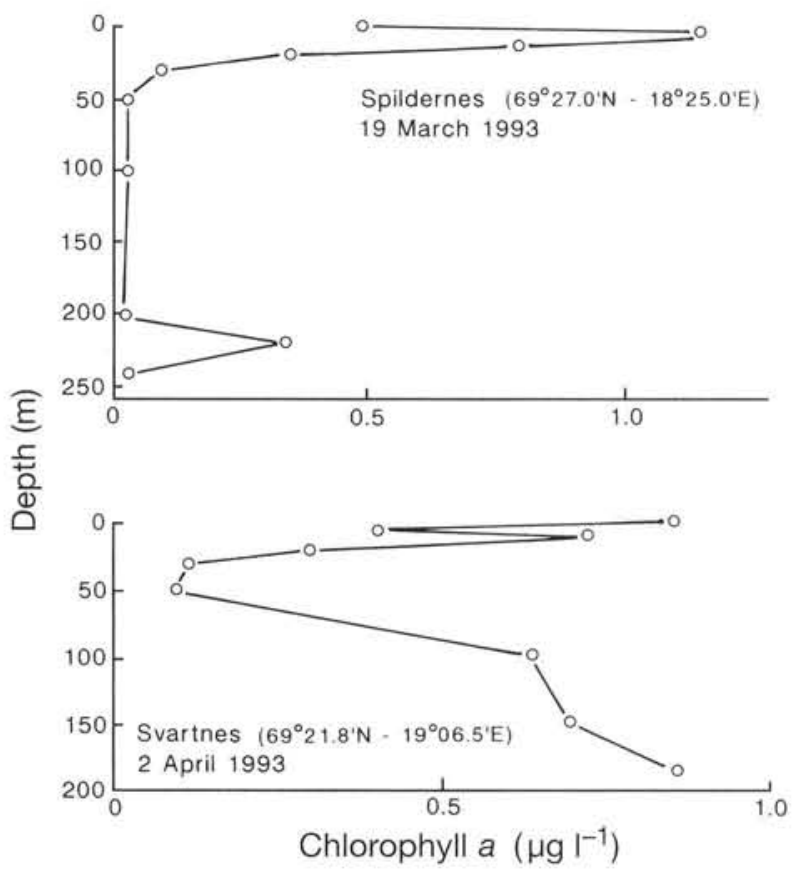

Fig. 1. Vertical distribution of phytoplankton biomass (chlorophyll a) in 2 fjord systems near Tromsø, Norway. Circles denote sampling depths

the surface layers, especially for the vertical profile from Svartnes in Balsfjord.

Replicate counts of identifiable resting spores in the sediment sample that was used during the daylength experiments yielded 1.9 to 4.6 million spores $\mathrm{ml}^{-1}$. No viable cells could be observed in the sediment.

At the lowest scalar irradiance $\left(2 \mu \mathrm{mol}\right.$ quanta $\left.\mathrm{m}^{-2} \mathrm{~s}^{-1}\right)$ in the first experiment (Table 2) we observed little or no growth of cells. At the 2 highest irradiances, Chaetoceros socialis, C. furcellatus, C. compressus, C. debilis, C. decipiens, C. subsecundus, C. curvisetus, C. teres, C. laciniosus, $C$. affinis and Thalassiosira nordenskioeldii grew only when daylength exceeded $11 \mathrm{~h}$.

Table 1. Phytoplankton cell counts (cells $1^{-1}$ ) from selected depths. Only the quantitatively most important species are included

\begin{tabular}{|lcccc|}
\hline & \multicolumn{2}{c}{ Svartnes (2 Apr 1993) } & Spildernes (19 Mar 1993) \\
Depth (m): & 0 & 180 & 0 & 240 \\
\hline Chaetoceros furcellatus & 5400 & & 3400 & \\
C. furcellatus resting spores & 1500 & 19000 & & \\
Chaetoceros socialis & 253000 & 39000 & 26000 & \\
C. socialis resting spores & & 59000 & & 3000 \\
Fragilariopsis oceanica & 2900 & 13000 & 4900 & \\
Navicula vanhoeffenii & 2000 & 1700 & 500 & 1000 \\
Skeletonema costatum & 7400 & 22000 & 15000 & \\
Thalassiosira gravida/rotula & 500 & & 2000 & \\
Thalassiosira nordenskioeldii & & 3500 & 2000 & \\
Phaeocystis pouchetii & 14000 & 95000 & 7000 & 1000 \\
\hline
\end{tabular}


Table 2. Experiments where sediment was exposed to varying daylengths. Number $(\times 1000)$ of viable cells $1^{-1}$ of the quantitatively most important species present at the termination of the experiment

\begin{tabular}{|c|c|c|c|c|c|c|c|c|c|c|c|c|}
\hline 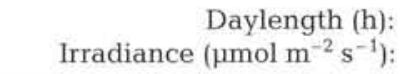 & 2 & $\begin{array}{c}7 \\
25\end{array}$ & 55 & 2 & $\begin{array}{l}11 \\
25\end{array}$ & 55 & 2 & $\begin{array}{l}13 \\
25\end{array}$ & 55 & 2 & $\begin{array}{l}17 \\
25\end{array}$ & 55 \\
\hline Skeletonema costatum & & 0.47 & 1.8 & & & 0.37 & & 11 & 9.4 & & 2.1 & 1.3 \\
\hline Chaetoceros gracilis & & 0.41 & 0.50 & 0.23 & 0.21 & & & 1.2 & 1.7 & 0.22 & 0.40 & 1.5 \\
\hline Chaetoceros socialis & & & & & & & & 6.1 & 8.7 & & 0.44 & 0.71 \\
\hline Chaetoceros furcellatus & & 0.34 & & & & & & 3.1 & 0.15 & & 0.28 & \\
\hline Chaetoceros compressus & & & & & & & & 2.3 & 5.4 & & 0.82 & 0.38 \\
\hline Chaetoceros debilis & & & & & & & & 10 & 2.4 & 0.19 & 0.55 & 1.6 \\
\hline Chaetoceros decipiens & & & & & & & & 4.8 & 8.7 & & 1.3 & 0.63 \\
\hline Chaetoceros subsecundus & & & & & & & & 3.1 & 0.99 & & & \\
\hline Chaetoceros curvisetus & & & & & & & & 3.5 & 9.4 & & 2.9 & 1.3 \\
\hline Chaetoceros teres & & & & & & & & 6.3 & 0.71 & & 0.61 & \\
\hline Chaetoceros laciniosus & & & & & & & & 0.76 & & & & \\
\hline Chaetoceros affinis & & & & & & & & 1.0 & 0.08 & & & \\
\hline Thalassiosira nordenskioeldii & & & & & & & & 1.3 & 0.30 & & 0.19 & 0.20 \\
\hline Fragilariopsis oceanica & & & 0.07 & 0.13 & 0.45 & 0.04 & & 0.41 & 0.42 & & 0.20 & 0.27 \\
\hline Fragilariopsis cylindrus & & & 0.07 & & 0.50 & 0.17 & & 0.44 & & & 0.25 & 0.21 \\
\hline Navicula vanhoeffenii & & & & 0.10 & & & & 0.23 & 8.8 & 0.26 & 2.6 & 0.30 \\
\hline Bacteriosira bathyomphala & & 1.0 & 3.3 & & 3.1 & 0.30 & & 1.0 & 4.8 & & 27 & 17 \\
\hline Rhizosolenia setigera f.s. & & & & & & & 0.20 & 0.89 & 0.35 & 0.11 & & 0.84 \\
\hline Odontella aurita & & 0.33 & 0.8 & 0.07 & & 0.23 & & 1.6 & 8.0 & & 0.73 & 1.6 \\
\hline Chaetoceros spp. & & 0.27 & & 0.03 & & & & 0.62 & 6.7 & & 0.50 & \\
\hline Thalassiosira spp. & 0.29 & 1.0 & 1.0 & 0.10 & 0.56 & 0.26 & 0.20 & 3.1 & 4.5 & 0.50 & 1.2 & 1.1 \\
\hline
\end{tabular}

The results from the second experiment, shown in Table 2, gave clear indication of higher abundances of the abovementioned species in samples where sediments were exposed to daylengths above 7 to $11 \mathrm{~h}$ at low light before being transferred to high light at $7 \mathrm{~h}$ daylength. Both experiments were terminated after $40 \mathrm{~d}$, and the tendency reported in the tables persisted throughout the experimental period.

Discussion. The relatively large amounts of resting spores in the water sample must, in our opinion, originate from the preceding year's spring bloom, since the winter situation in the region is characterised by negligible phytoplankton concentrations and no net phytoplankton growth due to the total absence of light during winter (Gaarder 1938, Eilertsen et al. 1981). The water (Fig. 1, Table 1) was sampled at the time of the onset of the spring bloom. At Spildernes we could only observe spores in the above-bottom samples, while at Svartnes, where sampling was performed later, we detected spores in both bottom and surface layers of the water column. We therefore interpret these observations as indicative of reinoculation of the water column and subsequent growth of germinated spores in the bottom layers. The typical bimodal biomass distribution (Fig. 1), also observed by us at other locations in the area and in the Barents Sea during onset of the spring bloom, at present lacks explanation.

The majority of the phytoplankters making up the spring bloom in northerly areas are resting-sporeforming species, and a lot of today's information pro- vides convincing evidence that resting spores function as survival stages in coastal populations (Kashkin 1964, Garrison 1984).

The results from our first experiment (Table 2) showed that there was a distinct photoperiodic response, in that some of the species failed to grow when exposed to daylengths shorter than $13 \mathrm{~h}$. These species are common members of the spring phytoplankton societies in northern areas. Skeletonema costatum (a species common in early winter/spring blooms at more southerly localities) was present in all cultures, irrespective of daylength. At southerly localities the early spring blooms, which occur under shortdaylength conditions, may often be dominated by $S$. costatum, whilst the other common spring diatom species bloom later when days are longer (Smayda 1983, Rines \& Hargraves 1987). The results from this experiment give a clear indication that daylength may be an important factor regulating the onset of phytoplankton blooms. However they did not provide evidence as to whether it was the germination of spores or the onset of growth that was regulated by daylength. In the second experiment (Table 3 ) we first exposed the sediment to various daylengths at a scalar irradiance below what is normally accepted as minimum light for net growth before we transferred the cells to high light at short daylength. The results from this experiment show a tendency towards higher abundances of the typical spring species in samples where sediments were exposed to daylengths above 7 to $11 \mathrm{~h}$ 
Table 3. Experiments with pre-exposure to low light $\left(2 \mu \mathrm{mol} \mathrm{m} \mathrm{m}^{-2} \mathrm{~s}^{-1}\right)$ before short-day high light exposure. Number $(\times 1000)$ of viable cells $1^{-1}$ of culture at termination of experiment

\begin{tabular}{|c|c|c|c|c|c|c|c|c|c|c|c|c|}
\hline \multicolumn{2}{|l|}{ Daylength $(\mathrm{h})$ : } & \multicolumn{2}{|l|}{7} & \multicolumn{3}{|c|}{11} & \multicolumn{3}{|c|}{13} & \multicolumn{3}{|c|}{17} \\
\hline to low light (h): & 2 & 7 & 14 & 2 & 7 & 14 & 2 & 7 & 14 & 2 & 7 & 14 \\
\hline Skeletonema costatum & 2.6 & 1.9 & 8.2 & 8.8 & 108 & 9.4 & 24 & 182 & 62 & 57 & 52 & 23 \\
\hline Chaetoceros gracilis & 1.9 & 1.4 & 0.14 & 1.4 & 193 & 8.9 & 1.0 & 1.8 & 0.07 & 0.22 & 0.29 & 0.08 \\
\hline Chaetoceros socialis & 0.74 & 0.12 & 0.40 & 2.5 & 19 & 8.2 & 101 & 42 & 48 & 10 & 7.5 & 28 \\
\hline Chaetoceros furcellatus & & & 0.43 & & 0.07 & 9.4 & 3.1 & 1.4 & 4.5 & & 0.14 & 8.4 \\
\hline Chaetoceros compressus & 0.47 & 0.60 & 0.21 & 3.0 & 0.40 & 8.2 & 1.2 & 5.0 & 28 & 0.27 & & 0.20 \\
\hline Chaetoceros debilis & 0.40 & & 1.2 & 12 & 3.6 & 36 & 23 & 18 & 38 & 1.5 & 0.80 & 2.0 \\
\hline Chaetoceros decipiens & 0.44 & & 0.55 & & 11 & 1.8 & 0.67 & 0.35 & 0.13 & 0.20 & 0.27 & 0.53 \\
\hline Chaetoceros subsecundus & 0.20 & 0.07 & & & 3.1 & 0.06 & 187 & 0.30 & 1.9 & 1.5 & & \\
\hline Chaetoceros curvisetus & & & & & & & & & & & & \\
\hline Chaetoceros teres & & & 0.07 & & & 3.8 & & 0.33 & 0.93 & 0.60 & 0.27 & 0.07 \\
\hline Chaetoceros laciniosus & & & & & & & 0.17 & & & & & \\
\hline Chaetoceros affinis & & & & & & & & & & & & \\
\hline Thalassiosira nordenskioeldii & 0.13 & 0.05 & 0.55 & 0.05 & 0.68 & 0.60 & 5.3 & 1.0 & 1.4 & 2.9 & 0.15 & 0.75 \\
\hline Fragilariopsis oceanica & & 0.27 & & & & 0.08 & & & & & & \\
\hline Fragilariopsis cylindrus & 0.67 & 0.27 & & & & 0.06 & & 0.09 & & & & 0.08 \\
\hline Navicula vanhoeffenii & & & 0.27 & & & 0.60 & & & & & & 0.20 \\
\hline Detonula confervaceae & 0.67 & 0.27 & & & & 0.60 & & 0.09 & & & & 0.08 \\
\hline Bacteriosira bathyomphala & & & & & & & & 0.93 & & 1.9 & & \\
\hline Nitzschia seriata & 0.13 & & & & & & & & & & & \\
\hline $\begin{array}{l}\text { Rhizosolenia setigera f.s. } \\
\text { Odontella aurita }\end{array}$ & & & 0.07 & & & & & 0.33 & & 0.21 & & 0.07 \\
\hline Leptocylindrus danicus & & & 0.07 & & & 0.30 & & & & & 0.07 & 0.07 \\
\hline Chaetoceros spp. & 3.7 & & & 101 & 2.3 & 6.8 & & 0.25 & & & & \\
\hline Thalasssiosira spp. & 4.8 & 2.6 & 1.4 & 4.8 & 9.7 & 5.3 & 9.4 & 21 & 0.33 & 3.7 & 8.1 & 0.64 \\
\hline
\end{tabular}

at low light. This may indicate that the germination of spores is photoperiod-regulated, but we cannot, from this, totally exclude daylength regulation of growth. The length of the dark period before the experiment was started may also have affected the results, and daylength-dependent triggering mechanisms may not be 'absolute', similar to what has been reported for land plants (Vince-Prue 1975).

Phytoplankton ecologists have had difficulties in explaining similar species successions at localities with different environmental regimes, and at given localities where year-to-year variations in conditions may be great (Smayda 1983, Karentz \& Smayda 1984). Ziemann et al. (1991) observed only 3 to 5 d interannual variability in the timing of the spring bloom in Auke Bay in Alaska. Ziemann et al. (1991) also concluded that the onset of blooms as controlled by factors other than mixed-layer and critical depth, and it is our suggestion that biological events like this may be explained by daylength-dependent germination of entrained spores.

In summary, we hypothesise that the onset of blooms in thoroughly mixed water columns may proceed as follows. (1) Resting spores/cells present in sediments are resuspended by turbulent mixing (wind, cooling, tidal currents). (2) Germination of spores and/or the onset of growth is regulated by daylength. Some species are
DNP (daylength-neutral plants) and others are LDP (long-day plants). (3) Progress of the bloom is regulated by the prevailing light conditions and the physical status of the water column (degree of mixing), but species succession is primarily controlled by photoperiod changes differentially affecting the DNP and LDP species.

The results presented here are preliminary, but nonetheless provide evidence that the study of photoperiodic responses of microalgae may be a fruitful avenue in the further evaluation of phytoplankton bloom triggering mechanisms, species succession and biogeography.

Acknowledgements. This work was supported by the Norwegian College of Fisheries Science (University of Tromsø). We thank T. Platt, O. Junttila and M. Jobling for valuable comments on the manuscript.

\section{LITERATURE CITED}

Dring, M. J., Lüning, K. (1983). Photomorphogenesis of marine macroalgae. In: Shropshire, W., Mohr, H. (eds.) Photomorphogenesis, Vol. 16B. Springer-Verlag, Berlin, p. $545-566$

Eilertsen, H. C., Schei, B., Taasen, J. P. (1981). Investigations on the plankton community of Balsfjorden, Northern Norway. The phytoplankton 1976-1978. Abundance, species composition, and succession. Sarsia 66: 129-141 
Eilertsen, H. C., Taasen, J. P., Weslawski, J. M. (1989). Phytoplankton studies in the fjords of West Spitzbergen: physical environment and production in spring and summer. J. Plankton Res. 11(6): 1245-1260

Evans, L. V., Callow, J. A., Vallow, M. E. (1982). The biology and biochemistry of reproduction and early development in Fucus. In: Round, F. E., Chapman, D. J. (eds.) Progress in phycological research. Elsevier Biomedical Press, Amsterdam, p. 67-111

Gaarder, K. R. (1938). Phytoplankton studies from the Tromsø district 1930-31. Tromsø Museums Årshefter Natur Historisk Avdeling 11(55): 1-59

Garrison, D. L. (1984). Plankton diatoms. In: Steidinger, K. A., Walker, L. M. (eds.) Marine plankton life cycle strategies. CRC Press, Inc., Boca Raton, FL, p. 1-17

Gran, H. H. (1912). Pelagic plant life. In: Murray, J., Hjort, J. (eds.) The depths of the ocean. Macmillan, London

Gros, P., Ryckaert, M. (1983). Étude de la production primaire phytoplanctonique dans les eaux littorales de la côte normande (Manche orientale). Oceanol. Acta 6(4): 453-450

Guillard, R. R., Ryther, J. H. (1962). Studies of marine planktonic diatoms. I. Cyclotella nana Hustedt, and Detonula confervaceae (Cleve) Gran. Can. J. Microbiol. $8(2): 229-239$

Hay, R. K. M. (1990). The influence of photoperiod on the drymatter production of grasses and cereals. New Phytol. 116: $233-254$

Heimdal, B. R. (1974). Composition and abundance of phytoplankton in the Ullsfjord area, North Norway. Astarte 7: $17-42$

Holm-Hansen, O., Lorenzen, C. J., Holmes, P. E., Strickland, J. D. H. (1965). Fluorometric determination of chlorophyll. J. Cons. perm. int. Explor. Mer 30: 3-15

This note was submitted to the editor
Karentz, D., Smayda, T. (1984). Temperature and seasonal occurrence patterns of 30 dominant phytoplankton species in Narragansett Bay over a 22 year period (1959-1980). Mar. Ecol. Prog. Ser. 18: 277-293

Kashkin, N. I. (1964). On the winter stock of planktonic algae in the sublittoral sediments. Tr. okeanol. Inst. Akad. Nauk. USSR 65: 49-57

Pedersen, T., Eliassen, J. E., Eilertsen, H. C., Tande, K. S. Olsen, R. E. (1989). Feeding, growth, lipid composition, and survival of larval cod (Gadus morhua L.) in relation to environmental conditions in an enclosure at $70^{\circ} \mathrm{N}$ in northern Norway. Rapp. P.-v. Réun. Cons. int. Explor. Mer 191: 409-420

Rines, J. E. B., Hargraves, P. E. (1987). The seasonal distribution of the marine diatom genus Chaetoceros Ehr. in Narragansett Bay, Rhode Island (1981-1982). J. Plankton Res. 9(5): 917-933

Schei, B. (1974). Phytoplankton investigations in Skjomen, a fjord in North Norway, 1970-1971. Astarte 7: 43-59

Smayda, T. J. (1983). The phytoplankton of estuaries. In: Ketchum, B. H. (ed.) Estuaries and enclosed seas. Elsevier Scientific Publishing Company, Amsterdam, p. 65-102

Sverdrup, H. U. (1953). On conditions for the vernal bloomimg of phytoplankton. J. Cons. perm. int. Explor. Mer 18: 287-295

Throndsen, J., Heimdal, B. (1976). Primary production, phytoplankton and light in Straumsbukta near Tromsø. Astarte 9: 51-60

Vince-Prue, D. (1975). Photoperiodism in plants. McGraw Hill, London

Ziemann, D. A., Conquest, L. D., Olaizola, M., Bienfang, P. K (1991). Interannual variability in the spring phytoplankton bloom in Auke Bay, Alaska. Mar. Biol. 109: 321-334

Manuscript first received: May 13, 1994

Revised version accepted: September 29, 1994 